Uşak Üniversitesi Sosyal Bilimler Dergisi

$2015,8 / 2$

\title{
Türk Tekstil ve Hazır Giyim Sektörünün Endüstri-İçi Ticaretinin Statik Analizi: AB-15 Ülkeleri İle Karşılaştırma
}

Dilek ŞAHİN*

\section{Öz}

Dünyanın en eski sanayi dalı olan tekstil ve hazır giyim sektörü gerek üretim sürecinde yaratılan katma değer, gerekse ihracat gelirlerindeki yüksek payı nedeniyle özellikle gelişmekte olan ülkelerin ekonomik kalkınma sürecinde önemli bir rol üstlenmektedir. Günümüz dış ticaretinde yeni bir olgu olan endüstri-içi ticaret aynı endüstriye ait malların hem ithal hem de ihraç edilmesi durumudur. Bu çalışmada Türkiye ve AB-15 ülkelerinin gerçekleştirmiş olduğu tekstil ticaretinin EİT yapısı ele alınmıştır. Bu kapsamda SITC65 ve SITC 84 ürün kodları GL endeksi kullanılarak hesaplanmıştır. Sonuç olarak AB-15 ülkelerinin çoğunun SITC 65 ve SITC 84 ürün kodlarının ticaretinin EIT şeklinde gerçekleştiği görülmüştür. Türkiye'nin SITC 65 ürün kodu ticareti EİT şeklinde gerçekleşirken SITC 84 ürün kodu ticaretinin EAT şeklinde gerçekleştiği sonucuna ulaşılmıştır.

Anahtar Kelimeler: Endüstri-İçi Ticaret, Tekstil ve Hazır Giyim Sektörü, AB-15 ve Türkiye.

\section{Static Analysis of Intra-Industry Trade of Turkish Textile and Apparel Industry: EU-15 Countries with Comparison}

\begin{abstract}
The world's oldest industries of textile and garment industry plays an important role, should value added in the manufacturing process, and export due to the high share of revenues, especially in the economic development process of developing countries. A new phenomenon in today's trade intra-industry trade of goods belonging to the same industry is the state to be both imported and exported. In this study, Turkey and the EU-15 countries of the textile trade was carried out by the Intra-industry trade structure is discussed. In this context, SITC65 and SITC 84 product codes are calculated using the GL index. As a result, most of the EU-15 countries SITC 65 and SITC 84 product code it was shown that the form of intra-industry trade in the trade. Turkey's SITC 65 product code is realized

* Öğr. Gör., Sivas Cumhuriyet Üniversitesi-Yıldızeli MYO
\end{abstract}


in the form of intra-industry trade SITC 84 product code has been concluded that the form of trade between the industry and commerce.

Key Words : Intra-Industry Trade, Textiles and Clothing Sector, EU15 and Turkey.

\section{Giriş}

Türkiye'nin diş ticaretinin önemli bir bölümü, gerek coğrafi konum gerekse tarihsel süreç içinde yaşanan gelişmeler nedeniyle Türkiye'nin en önemli ticaret ortağı konumunda olan AB ülkeleri ile gerçekleştirilmektedir. Son yıllarda imalat sanayinde üretim artışı ile ithal girdi kullanımı arasındaki ilişkiyi güçlendiren ve küreselleşmenin hızlanması ile giderek ağırlık kazanan olgulardan birisi de endüstri-içi ticaretteki gelişmelerdir. Dünyada EİT'nin önemi giderek artmakta ve özellikle gelişmiş ülkelerin dış ticaretleri bu yöne doğru kaymaktadır

Bu çalışmanın amacı, Türkiye ile dış ticaretin önemli bir bölümünü gerçekleştirdiği $A B-15$ ülkelerinin tekstil ve hazır giyim endüstrisi dış ticaretinde, bir ülkenin aynı endüstriye ait olan bir ürünü hem ihraç hem de ithal ettiği uluslararası ticaret türü olarak tanımlanan endüstri-içi ticaret yapısı ve önemini ortaya koymaktır. EIT hesaplamasında çeşitli yönetmeler kullanılmakla birlikte bunlardan bir kısmı statik(belirli bir zamandaki dış ticaret yapısını ölçen) bir kısmı ise dinamik (iki zaman dilimi arasındaki dış ticarette meydana gelen değişimi ölçen) bir özellik arz etmektedir. Çalışmada EİT ölçümünde sıkça kullanılan ve statik bir hesaplama yöntemi olan G-L endeksi kullanılmıştır. Grubel-Lloyd yöntemine göre hesaplanan GL endeksinin yükselmesi her zaman o sektörde EITT'nin artmasına işaret etmektedir.

\section{Endüstri-İçi Ticaret Kavramı}

Küreselleşmenin yoğun biçimde yaşandığı son yıllarda, uluslararası alandaki gelişmeler dış ticaret teorilerinin varsayımlarının değişmesine neden olmuştur. Dünya ticaretinin serbestleşmesi ve ekonomik entegrasyonlara gidilmesi beraberinde ülkelerin endüstri-içi ticaretini de artırmıştır.

Geleneksel iktisat teorisi, ülkeler arasındaki teknolojik veya faktör donanımları farklılıklarını ticaretin nedeni olarak ileri sürmektedir. Bu varsayımın geçerli olduğu bir dünyada uluslararası ticaretin kompozisyonu yansıtacak şekilde, ülkelerin göreli olarak daha fazla sahip oldukları üretim faktörlerini içeren malları ihraç etmelerini gerektirmektedir. Oysa gerçek dünyada ülkeler arasındaki dış ticaretin yapısı incelendiğinde, aynı 
Sosyal Bilimler Dergisi 51

endüstriye ait homojen veya benzer malların iki yönlü ticaretinin yapıldığı görülmektedir (Eşiyok, 2014: 116).

Son yıllarda dünya ticareti, benzer faktör donatımlarına sahip ülkeler arasında ve benzer ürünler üzerinden yapılan endüstri-içi ticaret şeklinde gerçekleşmektedir (Deviren ve Karataş, 2007: 17). Endüstri-içi ticaret, aynı endüstrideki malların hem ihraç hem de ithal edilmesidir (Grubel ve Lloyd, 1975: 21). Diğer bir ifadeyle, benzer girdi kullanımına sahip olan ve talep yapıları benzeşen malların aynı anda bir ülkenin hem ithalat hem de ihracat kalemleri içinde yer almasıdır (Narin, 2002: 7). Endüstri-içi ticaret kavramı ilk kez Balassa (1966) tarafından kullanılmıştır. Avrupa Ekonomik Topluluğu'nun kurulmasılyla birlikte topluluk içinde ticareti incelediği çalışmasında Balassa bu yeni dönemle birlikte özellikle sanayi malları ticaretinin endüstriler-arası ticaretten endüstri-içi ticarete dönüştüğünü görmüştür. Endüstri-içi ticaretin özellikle oligopol veya tekelci rekabet piyasalarında hakim olduğu görülmektedir. Endüstri-içi ticaretin artmasıyla beraber ihracatın belirli sektörlerde yoğunlaşması azalırken ihracat çeşitlenmesi artmaktadır.

EİT'nin ortaya çıkmasında, ürün farklılaştırması, taşıma maliyetleri ve coğrafi bölgeler ve dinamik ölçek ekonomileri, ülkelerin gelir dağılımındaki farklılıklar, gelmektedir. Bunları şu şekilde açıklamak mümkündür (Yenilmez ve Kutlu, 2005: 46).

Ürün farklllaştırması: Aynı endüstrinin ürünü olan fakat ufak farklılıklara sahip olan mallar tüketici zevk ve tercihlerindeki farklılıklar nedeniyle EİT'ye konu olmaktadır.

Taşıma maliyetleri ve coğrafik bölgeler: Fiziki olarak büyük ülkelerdeki uç bölgelerdeki üreticiler ulaşım masrafları nedeniyle sınır komşusu olan yakın ülkelerden ithalat yoluyla hammadde teminine gitmektedir.

Dinamik ölçek ekonomileri: Ülke bir ürünün çeşidinde uzmanlaştığında birim maliyetlerde azalma olacak ve ülke aynı maldan daha fazla üreterek ihraç edecek ve aynı ürünün farklı çeşidini daha ucuza ithal edecektir.

Ülkelerin gelir dağılımındaki farklllklar: Tüketici zevkleri gelir talebinden belirlenmekle birlikte, bir ülkede üretilen mal çeşitliliği kişi başına düşen gelir seviyesinin bir yansımasıdır.

Daha geniş piyasalardan yararlanma imkânı vermesi, ölçeğe göre artan getiri ve ürün farklılaştırması nedeniyle endüstri-içi ticaret, endüstriler arası ticaret göre daha yüksek kazanımlar sunmaktadır (Aydın, 2010: 2). Günümüz dış ticaretinin büyük bir kısmını oluşturan bu ticaret şekli özellikle gelişmiş ülkeler arasında ve kimya, makine, ulaşım araçları ve elektronik gibi daha sofistike imalat sektörlerinde oldukça yaygındır. 
Sermaye-emek oranı benzer yapıda olan ülkeler arasında endüstriiçi ticaretin yüksek düzeyde gerçekleştiği görülmektedir. Bir endüstride EİT düzeyinin yüksek olması belirgin bir karşılaştırmalı üstünlüğün oluşmadığını ve ülkelerin ilgili sektörlerde benzer gelişmişlik düzeylerine sahip olduğunu göstermektedir. Bu nedenle ülkeler arasında yapılan dış ticaretin endüstri-içi ticaret düzeyi yüksek olduğu sektör sayısı artıkça ülkeler arasındaki kalkınmışlık düzeylerinin birbirine yaklaştığından bahsedilebilir.

\section{EIT'nin Statik ve Dinamik Analizi}

EİT ile ilgili incelenmesi gereken önemli bir konuda endüstri-içi ticaretin ölçülmesidir. EİT'nin ölçülmesinde sıkça kullanılan yöntemlerden biri Grubel-Lloyd Endeksidir (GL).

GL endeksi şu şekilde formüle edilmektedir (Grubel ve Lloyd, 1975: 21):

$$
\text { veya } \quad B i=1-\frac{|X i-M i|}{X i+M i}
$$

GL endeksi, diş ticaret endüstrileri açısından ülkenin rekabet gücü ve dış ticaret biçimlerindeki gelişmelerin açılanmasına yardımcı olmaktadır. Bu eşitlikte $\mathrm{Xi}$ ve Mi i endüstrisinin ihracat ve ithalatını ifade etmektedir. Endeks 0 ile 1 arasında değer almakta ve endeksin 1'e yaklaşması endüstri-içi ticaretin geliştiğini göstermektedir. EİT'yi bir yıllık süre için ölçen GL endeksi statik bir ölçümdür. Bu nedenle endeks iki dönem arasında ortaya çıkan uzmanlaşma ve ticaret akımlarındaki değişikliklerin kaynağı hakkında bilgi vermemektedir.

Bu eksikliği ortadan kaldırmak amacıyla Hamilton ve Kniest (1991) ticaretteki yapısal değişime ilişkin bilgi veren marjinal endüstri-içi (MEIT) kavramını geliştirmişlerdir. Dış ticaret yapısının belirlenmesinde en çok kullanılan endeksler Brülthart'ın A ve B endeksleridir. Bu endeksler şu şekilde ifade edilmektedir (Brülhart, 1994: 606):

$$
A=1-\frac{|\Delta X-\Delta M|}{|\Delta X|+|\Delta M|}
$$

Bu endeks 0 ile 1 arasında bir değer almaktadır. Endeksin 0 değerini alması belli bir endüstrideki marjinal ticaretin tümüyle EAT; 1 değerini alması ise marjinal ticaretin tümüyle EIT yapısında olduğunu 
göstermektedir. A endeksi, ticaret tarafından uyarılan kazanç/kayıpların ülkeler veya sektörler arasındaki dağılımı hakkında bilgi vermediğinden, tek ülkeye ilişkin çalışmalarda sınırlı olarak kullanılmakta olup, çok ülkeli çalışmalar için uygun sonuçlar vermektedir. Bu nedenle Brülhart tarafından $B$ endeksi olarak ifade edilen yeni bir endeks tanımlanmıştır. Buna göre;

$$
B=\frac{\Delta X-\Delta M}{|\Delta X|-|\Delta M|}, \quad|B|=1-A \text { şeklinde yazılmaktadır. }
$$

Bu endeks -1 ile +1 arasında değer alabilir. Eğer bu değer 0 'a yaklaşıyorsa MEITT artmakta; endeks değeri 0 'a eşitse marjinal ticaret tümüyle EITT yapısına bürünmektedir.

\section{Dünyada ve Türkiye'de Tekstil Sektörü}

Tekstil ve hazır giyim sektörü, yarattı̆̆ı istihdam olanakları, kazandırdığı döviz gelirleri ve ürettiği katma değer ile dünya ekonomileri için, kalkınmanın sağlanmasında oldukça önemli bir sektördür.

Dünyadaki kalkınma sürecine bakıldığında kalkınmış ülkelerde tekstil ve hazır giyim sektörünün imalat sanayi içindeki payı sürekli azalırken gelişmekte olan ülkelerde imalat sanayi üretimi içinde tekstil ve hazır giyim sektörünün payı sürekli artmaktadır (Özçalık ve Okur, 2013: 212). 1980'lerden itibaren hız kazanan küreselleşme eğilimi beraberinde tekstil ve hazır giyim sanayinde ticaret akışını hızlandırmış ve bu nedenle bu sektör günümüzde en fazla "küreselleşmiş endüstrilerden" biri haline gelmiştir (Aydoğdu, 2012: 4).

Dünya Ticaret Örgütü tarafından 1995 yılında imzalanan ve 2005 sonrası tekstil ve hazır giyim ticaretinin tamamen serbestleştirilmesini öngören "Tekstil ve Hazır Giyim Anlaşmasıyla" birlikte 2001 yılında Çin'in DTÖ'ye üyeliği dünya tekstil ve hazır giyim sektöründe yeni bir dönem başlatmıştır.

Tekstil ve hazır giyim anlaşmasında tekstil ve hazır giyim ürünlerine uygulanan kısıtlamaların 2005 yılına kadar dört kademede ve her kademede artan oranlarda kaldırılması öngörülmüştür (Uzunoğlu, 2008: 23). Böylelikle Çin'in üretim merkezi olma dönemi başlamış, Bangladeş ve Vietnam gibi ülkeler gerek üretim maliyetlerinin düşük olması gerekse önemli ithalatçı ülkelerle imzalamış olduğu tercihli ticaret anlaşmaları ve düzenlemeleri sayesinde önemli üretici ve ihracatçı ülkeler konumuna erişmişlerdir. Tekstil ve hazır giyim sektörleri birbirleriyle doğrudan ilişkili sektörler olduğundan her dönem gelişmeleri paralellik göstermiştir. Tablo 1'de 1995-2013 yılları arasında dünya tekstil ve hazır giyim ihracatı yer almaktadır. Tablo 1'den elde edilen sonuca göre 1995'de tekstil sektörünün 
dünya ihracatındaki payı \%31,18 iken 2013 yılına gelindiğinde bu oran \%17,05 düzeyinde gerçekleşmiştir. Benzer şekilde, 1995'de hazır giyim endüstrisinin dünya toplam ihracatındaki payı \%32,44 iken bu oran 2013 yılına gelindiğinde \%24,30 seviyesinde gerçekleşmiştir. Genel itibariyle değerlendirildiğinde emek yoğun endüstri olan tekstil ve hazır giyim sektörünün halen önemini korumasıyla birlikte azaldığı gerçeği de görülmektedir.

Tablo 1. Dünya Tekstil ve Hazır Giyim İhracatı (1995-2013 milyon dolar \%)

\begin{tabular}{|c|c|c|c|c|c|}
\hline Y1llar & $\begin{array}{c}\text { Toplam } \\
\text { Dünya } \\
\text { İhracatı } \\
\text { (milyon } \\
\text { dolar) }\end{array}$ & $\begin{array}{c}\text { Dünya } \\
\text { Tekstil } \\
\text { İhracatı } \\
\text { (milyon } \\
\text { dolar) }\end{array}$ & $\begin{array}{c}\text { Tekstil } \\
\text { İhracatının } \\
\text { toplam } \\
\text { ihracattaki } \\
\text { \% payı }\end{array}$ & $\begin{array}{c}\text { Dünya } \\
\text { Hazır } \\
\text { Giyim } \\
\text { İhracatı } \\
\text { (milyon } \\
\text { dolar) }\end{array}$ & $\begin{array}{c}\text { Hazır Giyim } \\
\text { İhracatının } \\
\text { Toplam } \\
\text { İhracattaki } \\
\text { \% Payı }\end{array}$ \\
\hline 1995 & 946.416 & 295.181 & 31,18 & 307.059 & 32,44 \\
\hline 2000 & 1.232 .560 & 307.132 & 24,91 & 392.816 & 31,86 \\
\hline 2005 & 1.996 .130 & 405.805 & 20,32 & 571.992 & 28,65 \\
\hline 2006 & 2.332 .460 & 436.118 & 18,69 & 639.854 & 27,43 \\
\hline 2007 & 2.663 .430 & 471.666 & 17,70 & 718.954 & 26,99 \\
\hline 2008 & 3.086 .930 & 492.622 & 15,95 & 757.356 & 24,53 \\
\hline 2009 & 2.401 .880 & 441.460 & 18,37 & 665.065 & 27,68 \\
\hline 2010 & 2.911 .770 & 497.592 & 17,08 & 736.937 & 25,30 \\
\hline 2011 & 3.475 .990 & 577.984 & 16,62 & 861.757 & 24,79 \\
\hline 2012 & 3.378 .640 & 547.286 & 16,19 & 810.182 & 23,97 \\
\hline 2013 & 3.275 .460 & 558.529 & 17,05 & 796.203 & 24,30 \\
\hline
\end{tabular}

Kaynak: UN Comtrade Veri tabanından yola çıkarak tarafımızca düzenlenmiştir.

Dünyada tekstil ve hazır giyim ihracında öne çıkan ülkelere baktığımızda şekil 1'de görüldüğü üzere gerek tekstil gerekse hazır giyim ihracatında ilk sırada Çin'in yer aldığını görmekteyiz. Çin'in sırasıyla AB-27 ülkeleri, Hindistan ve Türkiye takip etmektedir. Türkiye'nin ihraç ettiği tekstil ve hazır giyim endüstrisi rakamlarının birbirine oldukça yakın olduğu dikkat çekmektedir. 


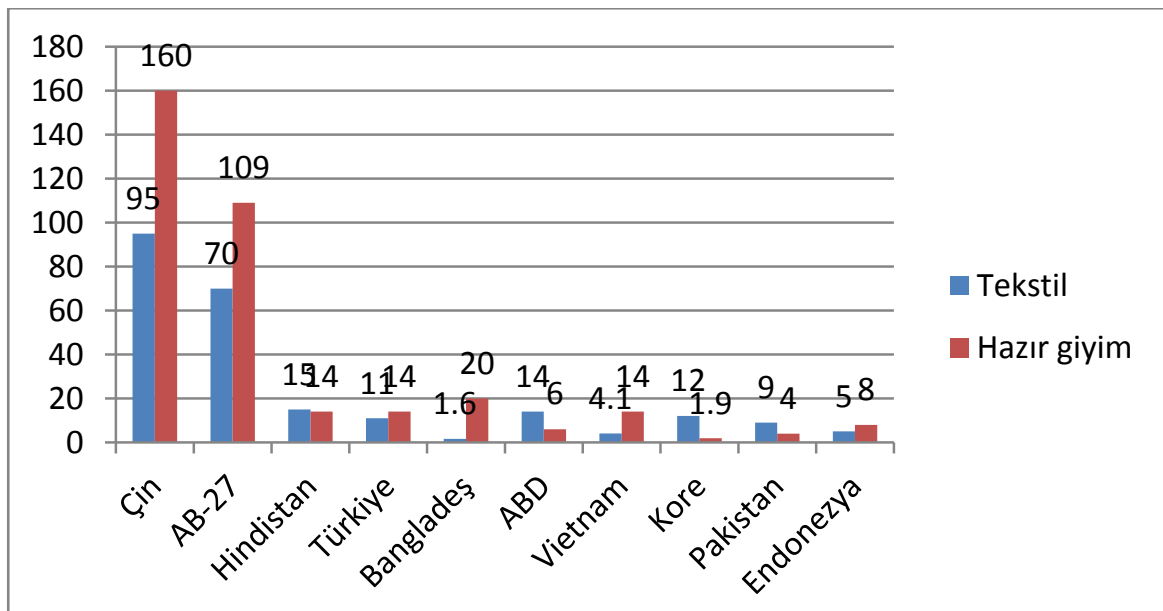

Şekil 1. Dünyada Başlıca Tekstil ve Hazır Giyim İhraç Eden Ülkeler-2012 (milyon dolar)

Kaynak: WTO, International Trade Statistics, 2013

http://www.wto.org/english/res_e/statis_e/its2013_e/its13_merch_trade_pro duct_e.pdf. (Erişim Tarihi: 16.09.2014).

Türkiye ekonomisinde tekstil sanayi uzun yıllardır rekabetçi düzeyde diğer ülkelere karşı üstün gelmekte ve ulusal geliri arttıran en önemli dış ticaret kalemi olmayı sürdürmektedir. Bunun yanı sıra emek yoğun sektörden daha çok sermaye yoğun bir sektör olan hazır giyim sektörü de tekstil sektörü kadar olmasa da Türkiye ekonomisinin ulusal geliri arttırıcı lokomotif sektörlerinden birisidir. Türkiye'de tekstil endüstrisinin istihdam ve ihracata sağlamış olduğu katkıdan dolayı, sosyoekonomik açıdan oldukça önemli bir rolü bulunmaktadır (Özkaya, 2010: 144). Türk tekstil ve hazır giyim sektörü diğer gelişmekte olan ülkelerde olduğu gibi lokomotif sektör konumundadır ve bu nedenle rekabetçiliğin artırrlarak devam etmesi oldukça önemlidir (Kök ve Çoban, 2005: 78). Üretim yapısı bakımından tekstil sanayi diğer sanayi dallarına göre daha az sermaye gerektiren işgücü yoğun üretim dalı olduğundan dolayı, Türkiye'nin üretim faktörleri yapısına da oldukça uygundur (Yücel, 2010: 231). Tablo 2' de Türkiye'nin tekstil ve hazır giyim ihracatının yıllar itibariyle gelişimini görmekteyiz. 1995'den itibaren gerek tekstil gerekse hazır giyim sektörü ihracatı yıllar itibariyle artış göstermektedir. Ancak 2008 Küresel finansal krizin etkisi tüm dünyada olduğu gibi ülkemizde tekstil ve hazır giyim ihracatında da etkisini göstermiş ve 2009 yllında sektördeki ihracat miktarı azalmıştır. Tekstil ve hazır giyim ihracatının toplam ihracat içindeki payına baktığımızda 1995'de \%40,02 olan oranın giderek azaldığı ve 2013 
yılına gelindiğinde bu oranın $\% 18,14^{\prime}$ e düşmüştür. Bunun nedenini Türkiye'nin toplam ihracatı içinde emek-yoğun sektörün payının azalması olarak açıklanabilir.

Tablo 2. Türkiye'nin Tekstil ve Hazır Giyim İhracatı (milyon dolar-\%)

\begin{tabular}{|c|c|c|c|c|c|}
\hline Yillar & $\begin{array}{l}\text { Toplam } \\
\text { İhracat }\end{array}$ & $\begin{array}{l}\text { Tekstil } \\
\mathbf{( 6 5 )}\end{array}$ & $\begin{array}{l}\text { Hazır } \\
\text { Giyim(84) }\end{array}$ & $\begin{array}{l}\text { Toplam } \\
\text { Tekstil ve } \\
\text { Hazır Giyim } \\
\text { İhracatı } \\
\mathbf{( 6 5 + 8 4 )}\end{array}$ & $\begin{array}{l}\text { Tekstil ve Hazır } \\
\text { Giyim } \\
\text { İhracatının } \\
\text { Toplam İhracat } \\
\text { İçindeki Pay1 (\%) }\end{array}$ \\
\hline 1995 & 21.598 & 2.526 & 6.118 & 8.644 & $\mathbf{4 0 , 0 2}$ \\
\hline 2000 & 27.485 & 3.672 & 6.533 & 10.205 & $\mathbf{3 7 , 1 2}$ \\
\hline 2005 & 73.476 & 7.075 & 11.833 & 18.908 & $\mathbf{2 5 , 7 3}$ \\
\hline 2006 & 85.534 & 7.584 & 12.051 & 19.635 & $\mathbf{2 2 , 9 5}$ \\
\hline 2007 & 107.271 & 8.942 & 13.886 & 22.828 & $\mathbf{2 1 , 2 8}$ \\
\hline 2008 & 132.002 & 9.399 & 13.590 & 22.989 & $\mathbf{1 7 , 4 1}$ \\
\hline 2009 & 102.138 & 7.723 & 11.555 & 19.278 & $\mathbf{1 8 , 8 7}$ \\
\hline 2010 & 113.979 & 8.963 & 12.760 & 21.723 & $\mathbf{1 9 , 0 5}$ \\
\hline 2011 & 134.915 & 10.772 & 13.947 & 24.719 & $\mathbf{1 8 , 3 2}$ \\
\hline 2012 & 152.536 & 11.054 & 14.289 & 25.343 & $\mathbf{1 6 , 6 1}$ \\
\hline 2013 & 151.796 & 12.150 & 15.395 & 27.545 & $\mathbf{1 8 , 1 4}$ \\
\hline
\end{tabular}

Kaynak: UN Comtrade Veri tabanından yola çıkarak tarafımızca düzenlenmiştir.

Tekstil endüstrisinde $A B$, Türkiye için en önemli pazardır. Tekstil endüstrisi için $A B^{\prime}$ nin en önemli pazar olmasının nedenleri arasında coğrafi yakınlık, $A B^{\prime}$ ye gümrüksüz ulaşım, göreceli düşük ücret düzeyi ve $A B^{\prime}$ nin yüksek kaliteli malları tercih etmesi bulunmaktadır (Uzay, 2005: 57-58). Taşıma maliyetleri ve ölçek ekonomilerinde sağlanan avantajlar, birlik içinde ticaretin artmasında önemli bir etken olmuştur. Türkiye'nin tekstil ve hazır giyim ihracatında en önemli pazarları arasında Almanya, İtalya, İngiltere, Fransa ve Hollanda gelmektedir. En büyük ticaret ortağımız olan Almanya tekstil ve hazır giyim ihracatında Türkiye'nin en önemli pazarıdır. AB-15 ülkeleri arasında Almanya, İngiltere ve İtalya en fazla tekstil ihraç edilen ülkelerdir. Almanya, İngiltere, Hollanda ve Fransa ise hazır giyim sektöründe en fazla ihracat yapılan ülkelerdir. 
Sosyal Bilimler Dergisi 57

Tablo 3. Türkiye'nin Tekstil ve Hazır Giyim İhracatında Önemli Pazar Payına Sahip AB -15 İçindeki Önemli Pazarlar (milyon dolar)

\begin{tabular}{|c|c|c|c|c|c|c|}
\hline Ülkeler & Sektör Kodu & $\mathbf{2 0 0 9}$ & $\mathbf{2 0 1 0}$ & $\mathbf{2 0 1 1}$ & $\mathbf{2 0 1 2}$ & $\mathbf{2 0 1 3}$ \\
\hline Almanya & 65 & 845,7 & 977,1 & $1,194.3$ & 977,1 & $1,090.3$ \\
\hline & 84 & $2,825.6$ & $3,069.6$ & $3,288.9$ & $2,965.7$ & $3,174.1$ \\
\hline İngiltere & 65 & 299 & 324,8 & 403,5 & 425,2 & 456,7 \\
\hline & 84 & $1,697.8$ & $1,953.5$ & $1,962.4$ & $2,114.6$ & $2,075.3$ \\
\hline Belçika & 65 & 137,5 & 155,1 & 174,8 & 166,9 & 199,8 \\
\hline & 84 & 290,9 & 363,8 & 386,5 & 354,1 & 384,5 \\
\hline Fransa & 65 & 297,8 & 347,6 & 402,6 & 309,3 & 350,8 \\
\hline & 84 & 901,4 & 1.015 .8 & 1.092 .0 & 896 & 962,8 \\
\hline Hollanda & 65 & 172,7 & 213,8 & 263,4 & 229,7 & 269,7 \\
\hline & 84 & 583,7 & 622 & 750,3 & 746,6 & 794,9 \\
\hline İtalya & 65 & 573 & 652,7 & 832,9 & 723,7 & 883,6 \\
\hline & 84 & 618,1 & 646,2 & 757,7 & 658 & 635 \\
\hline
\end{tabular}

Kaynak: UN Comtrade Veri Tabanı.

\section{Literatür İncelemesi}

1957 yılında imzalanan Roma Anlaşması'yla birlikte Avrupa'da ticaretin serbestleşmesi ve ekonomik bütünleşmenin gelişmesiyle birlikte, geleneksel ticaret teorisinin aksine endüstriler içi artan uzmanlaşma ve $A B$ ülkeleri arasındaki ticarette endüstri-içi ticaret (EITT) payının hızla artışı, yapılan EIT çalışmaların $\mathrm{AB}$ üzerine yapılmasına neden olmuştur. Literatürde EİT kapsamında yapılan bazı çalışmaları aşağıdaki gibi özetlemek mümkündür.

Çakmak (2006); Türkiye ile Almanya, İtalya, Fransa ve İngiltere arasında imalat endüstrisi dış ticaretinde EITT'nin yapısını ve önemini tespit etmek amacıyla 1991-2004 döneminde SITC Rev. 3, 3 basamaklı ürün grupları verileri ve standart G-L endeksi kullanılarak bir araştırma yapılmıştır. Buna göre, ilgili dönemde Türkiye ile dört ülke arasındaki EITT oranlarını temel alan sıralamanın zamanla çok değiştiği, söz konusu dönemin başlarında Türkiye ile imalat endüstrisi EITT düzeyi en yüksek ülkeler sırasıyla İngiltere, İtalya, Almanya ve Fransa iken, dönemin sonlarına doğru bu sıralama Fransa, İtalya, Almanya ve İngiltere biçiminde olduğu ifade edilmektedir.

Çeştepe (2012); Türkiye'nin ortak kültürel ve tarihi bağlarının olduğu seçilmiş Ortadoğu ülkeleriyle ticaretin yapısı analiz edilmiştir. Çalışmada 1999-2009 arasında dış ticaret verileriyle ticaret yoğunluğu, 
Grubel-Lloyd ve Balassa endeksleri hesaplanmıştır. Türkiye'nin bu ülkelerle dış ticaretinin arttığı, bu ticarette endüstri içi ticaret düzeyinin genel olarak düşük, işlenmiş mallarda nispeten yüksek olduğu ve Türkiye'nin bir iki mal grubu dışında söz konusu ülke grubuna göre rekabet gücünün bulunduğu görülmüştür. Türkiye'nin bu ülkelerle dış ticaretinin artması için, rekabet gücüne sahip olduğu sermaye yoğun malların ihracatına daha fazla ağırlık vermesi gerektiği sonucuna ulaşılmıştır.

Erk ve Tekgül (2001); 1993-1998 dönemi Türkiye ve AB arasında ticarete konu olan 97 ürün grubunun EIT ve yatay-dikey farklilaşma düzeyleri tespit edilmiştir. Çalışmaya göre, Türkiye ve $A B$ arasındaki ticaretin karşılaştırmalı üstünlüklere dayanmasının yanı sıra önemli bir kısmının EITT yapısında dikey mal farklılaşmasının olduğu ifade edilmektedir.

Erlat ve Erlat (2003); 1969-1999 dönemi için, SITC Rev.3'e göre 3 basamaklı sektörel verilerle, $15 \mathrm{AB}$ üyesi ülkeyi kapsayan dünya ticareti ile Türkiye'nin EİT'sinin statik ve dinamik yapısı analiz etmiştir. Çalışmada genel olarak ticaretin EAT yapısı sergilediği, ancak özellikle 1980 sonrası dönemde bu yapının az da olsa EİT'ye dönüştügü tespit edilmiştir. Ayrıca Brülhart'ın A, B ve C endeksleri kullanılarak da MEIT'nin, 1980 öncesi ve sonrasında önemli değişiklikler gösterdiği belirlenmiştir.

Erün(2010); Türkiye ve $A B$ ülkeleri arasında gıda ve canlı hayvan sektörü toplamında ve alt sektöründe 1995-2009 dönemleri itibariyle Grubel - Lloyd indeksi ve birim değer oranları hesaplanmıştır. Türkiye ile AB-15 ülkeleri arasındaki EITT giderek azaldığı ancak tek tek ülkelere bakıldığında özellikle Macaristan, Bulgaristan, Danimarka, İspanya, İrlanda ve Romanya ile olan gıda ve canlı hayvan sektöründe EIT'nin güçlü olduğu görülmüştür. Türkiye ile AB-15 ve AB-27 arasında yüksek kalitede EİT yapısıyla karşılaşılırken tek tek ülkeler için yapılan analize bakıldığında düşük kalitede dikey EITT yapısıyla karşılaşılmıştır.

Kaya ve Atış (2007); Türkiye'nin kimya sanayi ürünleri ithalat ve ihracatında öne çıkan ülkeler ile EIT'nin gelişimini araştırmışlardır. Bu çalışma, Türkiye ile belli başlı $\mathrm{AB}$ üyesi ve $\mathrm{AB}$ 'ye aday ülkeler arasında 19902005 dönemi ve SITC Rev.3'e göre 5 basamaklı kimya sanayi ürün grubuna ait verilerle, standart G-L endeksi kullanarak statik analiz, daha sonra Brülhart'ın marjinal EIT ticareti belirlemeye yönelik A ve B endeksleri kullanarak dinamik analiz gerçekleştirmektedir. Çalışmaya göre, Türkiye'nin kimya sanayi EİT düzeyi genel olarak sektör tüketiminin dişa bağımlı olması nedeniyle düşük seviyededir. Özellikle, son yıllarda bazı alt ürün gruplarındaki söz konusu ticaret, ticaretin serbestleştirilmesiyle birlikte artan ticaret ilişkileri ve zamanla yalnızca ihracatçı ya da ithalatçı olunan 
Sosyal Bilimler Dergisi 59

ürün gruplarında çift yönlü ticaret yapısına dönüşüm nedenleriyle EİT'e yönelmektedir.

Özkaya (2010); Türk tekstil sektöründeki endüstri-içi ticaretle ilgili gelişmeler 1989-2009 yılları için Grubel-Lloyd endeksi kullanılarak ortaya konulmuştur. Daha sonra yatay endüstri-içi ticaret ve dikey endüstri-içi ticaret ayrımının dikkate alınmış ve endüstri-içi ticareti etkileyen faktörleri tespit etmek amaciyla ülkeye ve sektöre özgü belirleyicileri esas alan regresyon analizi yapılmıştır. Bu analize göre kişi başına düşen gelir ve ölçek ekonomileri tekstil sektöründe endüstri-içi ticaret düzeyini olumlu etkilerken, doğrudan yabancı yatırım olumsuz etkilediği sonucuna ulaşılmıştır.

Yurttançıkmaz (2013); çalışmada Türkiye'nin 1995-2009 dönemi için $\mathrm{AB}$ ile olan dış ticaretinin EİT düzeyi ve EİT açısından avantajlı olduğu ürünler Grubel ve Lloyd ile Balassa Endeksi kullanılarak belirlenmiştir. Elde edilen sonuçlara göre Türkiye'nin gelişmesi ve ekonomik refahının artmasına bağlı olarak tüketim kalıbı, tercihleri ve alışkanlıkları açısından $\mathrm{AB}$ ülkelerine yaklaşmaktadır. Böylelikle $\mathrm{AB}$ ile olan diş ticaret daha endüstri içi bir hal alırken Türkiye'nin sanayi malları ile makine ve ulaşım araçları sektöründe genel olarak karşılaştırmalı üstünlük artarken tekstil sektörünü de içeren çeşitli mamul eşya sektörü ise giderek zayıflamaktadır.

\section{Model ve Veri Seti}

Çalışmada AB-15 ülkesi ile Türkiye'nin tekstil ve hazır giyim sektörünün EİT yapısı statik bir şekilde analiz etmek için, Grubel-Lloyd'un endüstri-içi ticaretin ölçümünde kullanılan GL endeksi kullanılmıştır. Uluslararası ticaret tasnifinde genel anlamıla tekstil endüstrisi üç başlık altında değerlendirilmektedir. Tekstil elyafları ve bunların atıklarını içeren hammadde grubu olarak SITC 26 grubu, tekstil ipliği, dokuma, mensucat ve ilgili ürünleri kapsayan SITC 65 grubu ve geniş kapsamlı hazır giyim ve aksesuarlarının yer aldığı SITC 84 grubudur. Ülkelerin ticaret performansları karşılaştırıldığında genellikle imalat sanayi ürünleri olmalarından dolayı SITC 65 ve SITC 84 grupları dikkate alınmaktadır.

Çalışmada Dünya Ticaret Örgütü tarafından hazırlanan “Uluslararası Standart Ticaret Sınıflandırması (SITC Rev.3) kullanılmıştır. GL endeksi, SITC Rev.3'e göre imalat sanayi alt dallarından tekstil (SITC65) ve Hazır Giyim (SITC84) sektörleri için hesaplanmıştır. G-L endeksini hesaplayabilmek için gerekli veriler http://comtrade.un.org/data/ veri tabanından derlenmiş olup çalışma verileri 1995-2013 yıllarını kapsamaktadır. SITC Rev.3'e göre tekstil ve hazır giyim endüstrisinin çalışma kapsamına alınan iki ve üç haneli ürün grupları Ek 1'de yer 
almaktadır. Literatürde bir endüstride yapılan ticaret (GL endeksi) eğer 0,50 den büyükse ilgili endüstride ticaretin EİT şeklinde; 0,50 küçük olması durumunda ise ticaretin EAT şeklinde gerçekleştiği kabul edilmektedir.

\section{Türkiye'nin Tekstil ve Hazır Giyim Sektörünün Endüstri-İçi Ticaretinin Karşılaştırmalı Analizi: Statik Bulgular}

Bu bölümde standart G-L endeksi kullanılarak incelenen dönemde Türkiye ile söz konusu ülkeler arasındaki tekstil ve hazır giyim sektörü için ihracat ve ithalat verileri ile ele alınan yıllar için EİT oranları hesaplanmıştır. Tablo 4'de Türkiye ile AB-15 ülkeleri arasında gerçekleşen ticaretin yönü (EIT-EAT) yer almaktadır.

Tabloda 4'de Türkiye'nin SITC 65 (tekstil endüstrisi) no'lu sektörde ticaretinin EITT şeklinde gerçekleştiği ancak SITC84 (hazır giyim endüstrisi) no'lu sektörde ticaretin EAT şeklinde olduğu görülmektedir. Diğer bir ifadeyle Türkiye SITC 65 ürün grubuna ait ticarette hem ithalat hem de ihracat yaparken-iki yönlü ticaret; SITC 84 ürün grubunda ise tek yönü ticaret yapmaktadır. AB-15 ülkelerine baktığımızda tekstil ve hazır giyim endüstrisinde yapılan ticaretin çoğunlukla EİT şeklinde gerçekleştiği görülmektedir. Özellikle SITC 65 ürün grubunda gerçekleştirilen ticaretin yönünün EİT şeklinde olduğu gözlenmektedir. Finlandiya, İrlanda ve İngiltere'nin SITC 84 ürün kodunda yapmış olduğu ticaretin 1995 yılında EIT şeklinde gerçekleştiği ancak izleyen yıllarda gerçekleştirilen ticaretin EAT şeklinde olduğu görülmektedir. Almanya, İtalya, Portekiz ve İsveç'te ise 1995 yllında SITC 84 ürün grubunda ticaretin EAT şeklinde gerçekleştiği görülmektedir. Bu durum esasında son dönemde özellikle gelişmiş ülkeler arasında EİT'nin giderek önem kazandığının bir kanıtıdır. 
Sosyal Bilimler Dergisi 61

Tablo 4. Standart G-L Endeksine Göre Hesaplanan Değerler

\begin{tabular}{|c|c|c|c|c|c|c|c|c|c|c|c|c|}
\hline Ülkeler & Kod & 1995 & 2000 & 2005 & 2006 & 2007 & 2008 & 2009 & 2010 & 2011 & 2012 & 2013 \\
\hline \multirow[t]{2}{*}{ Almanya } & 65 & 0,92 & 0,92 & 0,93 & 0,92 & 0,93 & 0,93 & 0,96 & 0,98 & 0,97 & 0,96 & 0,97 \\
\hline & 84 & * & 0,52 & 0,66 & 0,67 & 0,70 & 0,71 & 0,70 & 0,68 & 0,67 & 0,69 & 0,68 \\
\hline \multirow[t]{2}{*}{ Avusturya } & 65 & 0,99 & 0,98 & 0,99 & 0,99 & 0,97 & 0,98 & 0,97 & 0,97 & 0,97 & 0,99 & 0,98 \\
\hline & 84 & 0,58 & 0,60 & 0,65 & 0,64 & 0,65 & 0,64 & 0,59 & 0,57 & 0,58 & 0,57 & 0,57 \\
\hline \multirow[t]{2}{*}{ Belçika } & 65 & na & 0,72 & 0,71 & 0,73 & 0,74 & 0,75 & 0,75 & 0,76 & 0,79 & 0,77 & 0,77 \\
\hline & 84 & na & 0,89 & 0,92 & 0,92 & 0,95 & 0,96 & 0,95 & 0,94 & 0,95 & 0,95 & 0,97 \\
\hline \multirow[t]{2}{*}{ Danimarka } & 65 & 0,87 & 0,92 & 0,91 & 0,91 & 0,95 & 0,93 & 0,94 & 0,93 & 0,91 & 0,91 & 0,88 \\
\hline & 84 & 0,82 & 0,88 & 0,92 & 0,93 & 0,93 & 0,92 & 0,92 & 0,92 & 0,94 & 0,91 & 0,95 \\
\hline \multirow[t]{2}{*}{ Lüksemburg } & 65 & na & 0,72 & 0,81 & 0,83 & 0,78 & 0,75 & 0,68 & 0,59 & 0,63 & 0,66 & 0,69 \\
\hline & 84 & na & 0,46 & 0,61 & 0,60 & 0,60 & 0,39 & 0,47 & 0,50 & 0,44 & 0,44 & 0,45 \\
\hline \multirow[t]{2}{*}{ İspanya } & 65 & 0,97 & 0,94 & 0,91 & 0,91 & 0,90 & 0,91 & 0,96 & 0,95 & 0,96 & 0,99 & 0,98 \\
\hline & 84 & 0,59 & 0,69 & 0,63 & 0,63 & 0,62 & 0,65 & 0,73 & 0,71 & 0,71 & 0,81 & 0,86 \\
\hline \multirow[t]{2}{*}{ Finlandiya } & 65 & 0,75 & 0,77 & 0,72 & 0,71 & 0,73 & 0,73 & 0,59 & 0,65 & 0,63 & 0,62 & 0,62 \\
\hline & 84 & 0,51 & * & * & * & $*$ & * & * & 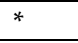 & 7 & 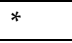 & * \\
\hline \multirow[t]{2}{*}{ Fransa } & 65 & 0,99 & 0,99 & 0,95 & 0,94 & 0,93 & 0,91 & 0,89 & 0,86 & 0,85 & 0,84 & 0,84 \\
\hline & 84 & 0,70 & 0,64 & 0,64 & 0,65 & 0,67 & 0,66 & 0,64 & 0,62 & 0,62 & 0,63 & 0,64 \\
\hline \multirow[t]{2}{*}{ İrlanda } & 65 & 0,99 & 0,90 & 0,72 & 0,62 & 0,55 & 0,59 & 0,58 & 0,65 & 0,67 & 0,64 & 0,59 \\
\hline & 84 & 0,74 & * & $*$ & . & * & . & * & $*$ & * & 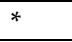 & * \\
\hline \multirow[t]{2}{*}{ İtalya } & 65 & 0,66 & 0,68 & 0,66 & 0,69 & 0,72 & 0,72 & 0,74 & 0,79 & 0,80 & 0,75 & 0,77 \\
\hline & 84 & $*$ & 0,62 & 0,79 & 0,82 & 0,81 & 0,81 & 0,88 & 0,90 & 0,88 & 0,83 & 0,79 \\
\hline \multirow[t]{2}{*}{ Hollanda } & 65 & 0,99 & 0,98 & 0,85 & 0,84 & 0,83 & 0,84 & 0,83 & 0,86 & 0,88 & 0,85 & 0,85 \\
\hline & 84 & 0,71 & 0,66 & 0,77 & 0,78 & 0,82 & 0,81 & 0,82 & 0,82 & 0,86 & 0,86 & 0,89 \\
\hline \multirow[t]{2}{*}{ Portekiz } & 65 & 0,90 & 0,95 & 0,96 & 0,97 & 0,98 & 0,98 & 0,96 & 0,97 & 0,97 & 0,93 & 0,99 \\
\hline & 84 & $*$ & 0,51 & 0,69 & 0,73 & 0,75 & 0,80 & 0,86 & 0,89 & 0,85 & 0,79 & 0,79 \\
\hline \multirow[t]{2}{*}{ İsveç } & 65 & 0,7 & 0,85 & 0,83 & 0,83 & 0,81 & 0,81 & 0,80 & 0,78 & 0,74 & 0,77 & 0,76 \\
\hline & 84 & $*$ & $*$ & 0,51 & 0,54 & 0,55 & 0,56 & 0,57 & 0,57 & 0,58 & 0,61 & 0,62 \\
\hline \multirow[t]{2}{*}{ Yunanistan } & 65 & 0,62 & 0,64 & 0,74 & 0,31 & 0,70 & 0,71 & 0,76 & 0,81 & 0,84 & 0,86 & 0,81 \\
\hline & 84 & 0,60 & 0,83 & 0,94 & 0,86 & 0,70 & 0,63 & 0,56 & 0,62 & 0,67 & 0,71 & 0,71 \\
\hline \multirow[t]{2}{*}{ İngiltere } & 65 & 0,77 & 0,72 & 0,73 & 0,73 & 0,73 & 0,71 & 0,69 & 0,68 & 0,67 & 0,70 & 0,69 \\
\hline & 84 & 0,70 & $*$ & * & $*$ & $*$ & * & * & $*$ & $*$ & * & $*$ \\
\hline \multirow[t]{2}{*}{ Türkiye } & 65 & 0,83 & 0,73 & 0,77 & 0,76 & 0,80 & 0,75 & 0,75 & 0,84 & 0,82 & 0,73 & 0,71 \\
\hline & 84 & * & * & * & * & * & * & * & $*$ & * & * & $*$ \\
\hline
\end{tabular}

Kaynak: UN Comtrade Database veri tabanından yola çıkılarak tarafımızca hesaplanmiştır.

*Endeks değeri 0,50'den büyük ise EİT olduğu kabul edilir. Burada * alanlar EİT olmadığını göstermektedir. na: İlgili yıla ilişkin veriye ulaşılamadığını ifade etmektedir.

Tablo 5'de SITC 65 ürün kodunun alt sektörler itibariyle ticaretinin yönü hesaplanmıştır. Buna göre Almanya ve İspanya'nın SITC 65 ürün kodunun tüm alt sektörler itibariyle ticaretinin EİT şeklinde olduğu görülmektedir. Bu ülkeler dışında diğer ülkelerin alt sektörlerde ticaret hem EITT hem de EAT şeklinde gerçekleşmiştir. Türkiye' de ise SITC 655, SITC658 
ve SITC659 kodlu alt sektörlerde ticaretin EAT şeklinde olduğu görülmektedir. Burada dikkat çeken bir husus da Türkiye'nin SITC 65 kodlu ticaretin tamamının EITT şeklinde gerçekleşirken alt sektörler itibariyle bu durumun bazı alt sektörlerde değişmesidir.

Tablo 5. Tekstil Sektörü Alt Sektörler İtibariyle G-L Endüstri-İçi Ticaret Endeksi (2013)

\begin{tabular}{|l|l|l|l|l|l|l|l|l|l|}
\hline Ülkeler & $\mathbf{6 5 1}$ & $\mathbf{6 5 2}$ & $\mathbf{6 5 3}$ & $\mathbf{6 5 4}$ & $\mathbf{6 5 5}$ & $\mathbf{6 5 6}$ & $\mathbf{6 5 7}$ & $\mathbf{6 5 8}$ & $\mathbf{6 5 9}$ \\
\hline Almanya & 0,81 & 0,87 & 0,87 & 0,97 & 0,67 & 0,78 & 0,67 & 0,73 & 0,70 \\
\hline Avusturya & 0,93 & 0,69 & $*$ & 0,91 & 0,87 & $*$ & 0,88 & 0,66 & $*$ \\
\hline Belçika & 0,98 & 0,91 & 0,68 & 0,62 & 0,89 & 0,86 & 0,79 & 0,87 & $*$ \\
\hline Danimarka & 0,63 & 0,87 & 0,89 & 0,86 & 0,91 & 0,99 & 0,79 & 0,81 & 0,64 \\
\hline Lüksemburg & $*$ & $*$ & 0,98 & $*$ & $*$ & $*$ & $*$ & 0,72 & $*$ \\
\hline İspanya & 0,92 & 0,78 & 0,86 & 0,85 & 0,79 & $*$ & 0,86 & 0,68 & 0,70 \\
\hline Finlandiya & $*$ & 0,64 & $*$ & 0,64 & 0,63 & 0,80 & 0,99 & $*$ & $*$ \\
\hline Fransa & 0,74 & 0,99 & 0,93 & 0,95 & 0,92 & 0,66 & 0,99 & $*$ & 0,68 \\
\hline İrlanda & $*$ & $*$ & $*$ & $*$ & $*$ & $*$ & 0,89 & $*$ & $*$ \\
\hline İtalya & 0,98 & 1 & 0,64 & $*$ & 0,72 & 0,74 & 0,57 & 0,76 & 0,98 \\
\hline Hollanda & 0,86 & 0,66 & 0,98 & 0,93 & 0,91 & 0,63 & 0,90 & 0,82 & $*$ \\
\hline Portekiz & $*$ & 0,77 & 0,99 & 0,59 & 0,83 & 0,88 & 0,61 & $*$ & 086 \\
\hline İsveç & $*$ & 0,55 & 0,68 & 0,92 & 0,68 & 0,79 & 0,96 & 0,61 & 0,62 \\
\hline Yunanistan & 0,82 & 0,74 & $*$ & $*$ & 0,99 & 0,84 & 0,93 & $*$ & $*$ \\
\hline İngiltere & 0,60 & 0,85 & 0,88 & 0,66 & 0,73 & 0,87 & 0,91 & $*$ & $*$ \\
\hline Türkiye & 0,73 & 0,79 & 0,68 & 0,68 & $*$ & 0,63 & 0,95 & $*$ & $*$ \\
\hline
\end{tabular}

Kaynak: UN Comtrade Database veri tabanından yola çıkılarak tarafımızca hesaplanmıştır.

Tablo 6'da ise SITC 84 ürün kodunun alt sektörler itibariyle ticaretinin yönü hesaplanmıştır. Alt sektörler itibariyle Almanya, Belçika, Danimarka, İspanya, İtalya, Hollanda, Portekiz ve İsveç'te ticaretin EİT şeklinde gerçekleştiği görülmektedir. Finlandiya ve İrlanda da ise alt sektörlerin tamamında ticaret EAT şeklinde gerçekleşmiştir. Türkiye'de ise gerek SITC 84 gerekse alt sektör gruplarında ticaretin tamamı EAT şeklinde gerçekleşmektedir. 
Sosyal Bilimler Dergisi 63

Tablo 6. Hazır Giyim Sektörünün Alt Sektörler İtibariyle G-L Endüstri-İçi Ticaret Endeksi (2013)

\begin{tabular}{|l|l|l|l|l|l|l|l|}
\hline Ülkeler & $\mathbf{8 4 1}$ & $\mathbf{8 4 2}$ & $\mathbf{8 4 3}$ & $\mathbf{8 4 4}$ & $\mathbf{8 4 5}$ & $\mathbf{8 4 6}$ & $\mathbf{8 4 8}$ \\
\hline Almanya & 0,72 & 0,68 & 0,62 & 0,67 & 0,73 & 0,69 & 0,73 \\
\hline Avusturya & $*$ & 0,52 & 0,53 & 0,78 & 0,59 & 0,60 & 0,68 \\
\hline Belçika & 0,97 & 0,86 & 0,82 & 0,94 & 0,98 & 0,97 & 0,99 \\
\hline Danimarka & 0,94 & 0,98 & 0,80 & 0,97 & 0,97 & 0,84 & 0,72 \\
\hline Lüksemburg & $*$ & $*$ & $*$ & $*$ & 0,73 & $*$ & $*$ \\
\hline İspanya & 0,77 & 0,95 & 0,65 & 0,79 & 0,90 & 0,75 & 0,73 \\
\hline Finlandiya & $*$ & $*$ & $*$ & $*$ & $*$ & $*$ & $*$ \\
\hline Fransa & $*$ & 0,61 & 0,52 & 0,58 & 0,72 & 0,68 & 0,77 \\
\hline İlanda & $*$ & $*$ & $*$ & $*$ & $*$ & $*$ & $*$ \\
\hline İtalya & 0,83 & 0,68 & 0,93 & 0,97 & 0,88 & 0,53 & 0,62 \\
\hline Hollanda & 0,92 & 0,85 & 0,99 & 0,82 & 0,89 & 0,93 & 0,97 \\
\hline Portekiz & 0,85 & 0,97 & 0,76 & 0,70 & 0,68 & 0,68 & 0,82 \\
\hline İsveç & 0,66 & 0,63 & 0,52 & 0,53 & 0,61 & 0,57 & 0,73 \\
\hline Yunanistan & $*$ & $*$ & $*$ & 0,96 & $*$ & 0,65 & 0,56 \\
\hline İngiltere & $*$ & 0,52 & $*$ & $*$ & $*$ & $*$ & 0,51 \\
\hline Türkiye & $*$ & $*$ & $*$ & $*$ & $*$ & $*$ & $*$ \\
\hline
\end{tabular}

Kaynak: UN Comtrade Database veri tabanından yola çıkılarak tarafımızca hesaplanmıştır.

\section{Sonuç}

EIT dış ticarette en yaygın olarak görülen ticaret şeklidir. EITT ilk olarak AET kurulmasıyla önem kazanmış ve bölge içinde serbest ticaretin başlaması farklılaştıılmış ürünlerin satılmasını ve üretim hacminin genişlemesini sağlamıştır. $A B$, Türkiye'nin diş ticaretinde önemli bir yer teşkil etmektedir. Tekstil ve hazır giyim sektörü ülkemizde ihracat ve üretimdeki yüksek payı nedeniyle oldukça önemli bir sektör olmakla birlikte yaşanan gelişmeler doğrultusunda sektörün rekabet gücü ve sektördeki ticaretin yönü değişmektedir. Değişen piyasa koşulları sonucunda tekstil sektörü en fazla küreselleşen dolayısıyla en fazla rekabete maruz kalan sektördür. Bu nedenle sektörde, rekabet gücü kavramı giderek daha önemli hale gelmiştir. Artan ekonomik büyüme, üretim metotlarında uzmanlaşma, ölçek ekonomileri, tüketici talebinde çeşitlilik, ürün farklılaştırması ve ekonomik entegrasyonlar sonucunda endüstri-içi ticaretin hızla artığını görülmektedir. 
EİT'nin tekstil ve hazır giyim endüstrisinde incelendiği bu çalışmada Türkiye ve AB-15 ülkelerinin tekstil ve hazır giyim sektöründe yaptıkları ticaretin yönü ortaya konulmuştur. Çalışmada sonuç olarak Türkiye'nin tekstil sektöründe ticaretinin yönü EİT şeklinde gerçekleşirken hazır giyim sektöründe EAT şeklinde gerçekleşmektedir. AB-15 ülkelerinin ise tekstil ve hazır giyim sektöründe ticaretinin yönü çoğunlukla EİT şeklinde gerçekleşmekle birlikte bazı ülkelerde ve bazı alt sektörler itibariyle durumun değiştiği görülmektedir.

\section{Kaynakça}

AYDIN, A. (2010). "Türkiye'nin Ticari Hizmetler Endüstri-İçi Ticareti." Ekonomi Bilimleri Dergisi, 2(2), 1-10.

AYDOĞDU, G. (2012). "Hazır Giyim ve Konfeksiyon Raporu." Çukurova Kalkınma Ajansı Raporu, 1-34.

BRÜLHART, M. (1994). "Marginal Intra-Industry Trade: Measurement and Relevance for the Pattern of Industrial Adjustment." Weltwirtschaftliches Archiv, Vol.130: 600-13.

ÇAKMAK, Ö. (2006). “Türkiye ile Almanya, İtalya, Fransa ve İngiltere Arasında İmalat Endüstrisinde Endüstri-İci Ticaretin Yapısı: 19912004." Ekonomik ve Sosyal Araştırmalar Dergisi, 3(1), 30-47.

ÇEŞTEPE, H. (2012). “Türkiye'nin Seçilmiş Ortadoğu Ülkeleriyle Ticaretinin Analizi." Ekonomik ve Sosyal Araştırmalar Dergisi, 8( 2), 23-43.

ÇOBAN, O. ve KÖK, R. (2005). “Türkiye Tekstil Endüstrisi ve Rekabet Gücü: AB Ülkeleriyle Karşılaştırmalı Bir Analiz Örneği, 1989-2001". İktisat İşletme ve Finans, 20(228), 68-81.

DEVIREN, N. ve KARATAŞ, M. (2007). “ Türkiye ile Çin Halk Cumhuriyeti Arasındaki Endüstri-İçi Ticaret", İktisat İşletme ve Finans, 22, 16-32.

DİLBER, İ. (2004)." Tekstil ve Konfeksiyon Sanayinin Rekabet Gücü." Yönetim ve Ekonomi, 11(2), 85-97.

ERK, N. ve TEKGÜL, Y. (2001). “Ekonomik Entegrasyon ve Endüstri-İçi Ticaret: Türkiye- $\mathrm{AB}$ Ülkeleri arasındaki Endüstri-İçi Ticaretin Ölçülmesi ve Ticaret Tipinin Belirlenmesi. " METU International Conference on Economics V, 1-34.

ERLAT, G. ve ERLAT, H. (2003). “Measuring Intra-Industry and Marginal Intra-Industry Trade: The Case for Turkey." Emerging Markets Finance and Trade, 39(6), 5-38.

ERÜN, G. (2010). “Türkiye ile AB, Gıda ve Canlı Hayvan Sektörü Dış Ticaretinde Endüstri-İçi Ticaret Analizi." Ekonomi Bilimleri Dergisi, 2(1), 71-78. 
Sosyal Bilimler Dergisi 65

EŞIYYOK, A. (2014). “Türkiye-AB Arasında Dış Ticaretin Teknolojik Yapısı, Rekabet Gücü ve Endüstri-İçi Ticaret: Ampirik Bir Değerlendirme", Ankara Avrupa Çalışmaları Dergisi, 13(1) , 91-124.

GRUBEL, H. ve LLOYD, P. (1975). Intra-Industry Trade: The Theory and Measurement of International Trade in Differentiated Products London: MacMillan Pres.

KAYA, A. ve ATIŞ, A. (2007). "Türkiye Kimya Sanayi Endüstri-İçi Ticaretinin Statik ve Dinamik Analizi: Avrupa Birliği Üye ve Aday Ülkeleri, Rusya Federasyonu, Ukranya ve Çin.” Ege Akademik Bakış, 7(1), 251-291.

MERCAN, M. ve YERGINN, H. (2011). “Gümrük Birliği'nin Türkiye Almanya Arasındaki Dış Ticaret ve Marjinal Endüstri-İçi Ticarete Etkisi, Endüstri-İçi Ticaretle Karşılaştırılması ve Alternatif Endeks", Anadolu İnternational Conference in Economics II .1-19.

NARİN, P. (2002)." Endüstri-İçi Ticaret ve İhracata Dayalı Sektörler Açısından Türkiye Uygulaması", Dokuz Eylül Üniversitesi Sosyal Bilimler Enstitüsü Dergisi, 4(1), 1-212.

ÖZÇALIK, M. ve OKUR, A. (2013). “Türk Tekstil ve Hazır Giyim Sektörlerinin Gümrük Birliği Sonrası AB-15 Ülkeleri Karşısındaki Rekabet Gücü." CBÜ Sosyal Bilimler Dergisi, 11(1), 205-223.

ÖZKAYA, H. (2010). "Tekstil Sektöründe Endüstri-İçi Ticareti Etkileyen Faktörler Üzerine Ampirik Çalışma." Uşak Üniversitesi Sosyal Bilimler Dergisi, 3(2), 136-157.

UZAY, N. (2005). “Değişen Dünya Koşullarında Türkiye'de Tekstil ve Hazır Giyim Sektörünün Geleceği", İşletme ve Finans Dergisi, 228, 54-67.

UZUNOĞLU, H. (2008)."Türk Hazır Giyim ve Tekstil Sektörünün 2008 Y1lı Rekabet Durumu." Ar-Ge Bülten, 23-27. http://www.izto.org.tr/portals/0/iztogenel/dokumanlar/turk_hazir_g iyim_ve_tekstil_sektorunun_2008_ii_h_uzunoglu_26.04.2012\%202025-02.pdf Erişim Tarihi: 16.11.2014

WTO, International $\quad$ Trade $\quad$ Statistics, 2013 http://www.wto.org/english/res_e/statis_e/its2013_e/its13_merch_tra de_product_e.pdf. Erişim Tarihi: 16.09.2014

YENER, Y. (2010). “Uluslararası Ticaretin Serbestleştirilmesi Sürecinde Türk Tekstil ve Hazır Giyim Sektörünün Rekabet Gücü ve Çin Tehdidi." Marmara Üniversitesi, İ̈BF Dergisi, 29(2), 227-250.

YENILMEZ, F. ve KUTLU, E.(2005). “Türkiye ile Avrupa Birliği Ülkeleri Arasındaki Endüstri-İçi Ticaretin Önemi", İktisat İşletme Finans, ss.45-64. 
YURTTANÇIKMAZ, Ç. (2014). “Türkiye'nin AB Pazarında Endüstri-İ̇çi Ticaret Açısından Avantajlı Olduğu Ürünlerin Belirlenmesi." C.Ü İktisadi ve İdari Bilimler Fakültesi , 14(1), 1-22.

http://comtrade.un.org/data/

Ek 1. SITC Rev.3'e Göre Tekstil ve Hazır Giyim Endüstrisi

\begin{tabular}{|c|c|c|c|}
\hline Sektörler & & Sektörler & \\
\hline SITC65 & $\begin{array}{l}\text { Tekstil ipliği, dokuma } \\
\text { mencusat ilgili ürünler }\end{array}$ & SITC84 & $\begin{array}{l}\text { Hazır giyim ve } \\
\text { aksesuarları }\end{array}$ \\
\hline 651 & Dokuma İplikleri & 841 & Erkek giyim eşyası \\
\hline 652 & $\begin{array}{l}\text { Pamuklu } \\
\text { dokumalar }\end{array}$ & 842 & Kadın giyim eşyası \\
\hline 653 & $\begin{array}{l}\text { Sentetik-suni elyaftan } \\
\text { dokuma }\end{array}$ & 843 & $\begin{array}{l}\text { Erkekler için örme } \\
\text { giyim eşyası }\end{array}$ \\
\hline 654 & $\begin{array}{l}\text { Pamuk, sentetik, suni elyaf } \\
\text { dışı liflerden } \\
\text { mensucat }\end{array}$ & 844 & $\begin{array}{l}\text { Kadınlar için örme } \\
\text { giyim eşyası }\end{array}$ \\
\hline 655 & -Poliester liflerden mensucat & 845 & Diğer giyim eşyası \\
\hline 656 & $\begin{array}{l}\text { Kordela, etiket, arma ve } \\
\text { benzeri } \\
\text { dokumalar }\end{array}$ & 846 & $\begin{array}{l}\text { Külotlu çorap, çorap, } \\
\text { soket, eldiven, } \\
\text { şal, atkı vb. }\end{array}$ \\
\hline 657 & $\begin{array}{l}\text { Özel dokumalar ve } \\
\text { bunlardan mamul } \\
\text { eşya }\end{array}$ & 848 & $\begin{array}{l}\text { Dokuma dışındaki } \\
\text { materyalden mamul } \\
\text { giyim eşyası }\end{array}$ \\
\hline 658 & Dokunmuş hazır eşya & & \\
\hline 659 & Yer kaplamaları, halılar & & \\
\hline
\end{tabular}

Kaynak: UN, Commodity Trade Statistics Database (COMTRADE) 